PART III. OTHERS

DZIAŁ III. INNE

\title{
FUNCTIONAL DIAGNOSTICS AND PHYSIOTHERAPEUTIC TREATMENT IN DE QUERVAIN SYNDROME
}

\section{DIAGNOSTYKA FUNKCJONALNA I LECZENIE FIZJOTERAPEUTYCZNE W ZESPOLE DE QUERVAINA}

\author{
Kamil Zaworski ${ }^{1(\mathrm{~A}, \mathrm{~B}, \mathrm{D}, \mathrm{E}, \mathrm{F})}$
}

${ }^{1}$ Pope John Paul II State School of Higher Education in Biała Podlaska, Poland

Authors' contribution Wkład autorów:

A. Study design/planning zaplanowanie badań B. Data collection/entry zebranie danych C. Data analysis/statistics dane - analiza i statystyki D. Data interpretation interpretacja danych E. Preparation of manuscript przygotowanie artykułu F. Literature analysis/search wyszukiwanie i analiza literatury G. Funds collection zebranie funduszy
Tables: 1

Figures: 0

References: 39

Submitted: 2020 Apr 30

Accepted: 2020 May 18

\section{Summary}

De Quervain syndrome involves the inflammation of the common tendon sheath of the abductor pollicis longus (APL) and the extensor pollicis brevis (EPB) in the region of the radial styloid process. This condition can be caused by microtraumas that occur in the course of repetitive mechanical activities and systemic diseases of the connective tissue, such as rheumatoid arthritis. The symptom of de Quervain syndrome is pain in the forearm at the height of the radial styloid process. The pain intensifies during the extension of the thumb. Other symptoms include redness and swelling in the region. The physical examination most often involves two tests: Finkelstein's test and Eichhoff's test. Physiotherapeutic treatment is an important element of conservative treatment of de Quervain syndrome. The article aims to present functional diagnostics and physiotherapeutic methods that are used in the treatment of de Quervain syndrome based on the available literature. The review used the division of therapeutic methods into three basic sections: kinesitherapy, physical therapy and therapeutic massage, and was expanded to include physioprophylaxis and education, kinesiotaping and acupuncture. The discussed publications noted a significant improvement in terms of reducing pain and functionality in patients with de Quervain syndrome using various physiotherapeutic methods and their combinations. Unfortunately, there is a small number of randomized clinical trials. Hence, it is difficult to draw clear conclusions about the most effective forms of treatment. Further research is required in order to achieve the integration of the most effective physiotherapeutic methods in the treatment of de Quervain syndrome and the assessment of its short and long-term effects.

Keywords: tendinitis, diagnosis, treatment, de Quervain, physiotherapy

\section{Streszczenie}

Zespół de Quervaina to stan zapalny wspólnej pochewki ścięgna odwodziciela długiego kciuka (APL) i prostownika krótkiego kciuka (EPB) w okolicy wyrostka rylcowatego kości promieniowej. Ta jednostka chorobowa może być spowodowana mikrourazami w przebiegu powtarzalnych czynności mechanicznych i chorobami układowymi tkanki łącznej, takimi jak zapalenia o charakterze reumatoidalnym. Objawy zespołu de Quervaina to dolegliwości bólowe przedramienia na wysokości wyrostka rylcowatego kości promieniowej nasilające się podczas prostowania kciuka. Także w tym rejonie może pojawić się zaczerwienienie oraz obrzęk. W badaniu przedmiotowym najczęściej wykorzystywane są dwa testy: Finkelsteina i Eichhoffa. Leczenie fizjoterapeutyczne jest ważnym elementem leczenia zachowawczego zespołu de Quervaina. Celem artykułu jest przedstawienie diagnostyki funkcjonalnej oraz metod fizjoterapeutycznych w leczeniu zespołu de Quervaina na podstawie dostępnej literatury. W przeglądzie zastosowano podział metod leczniczych na trzy podstawowe działy: kinezyterapię, fizykoterapię i masaż leczniczy oraz rozszerzono go o fizjoprofilaktykę i edukację, kinesiotaping oraz akupunkture. W omawianych publikacjach odnotowano istotną poprawę w kwestii obniżenia dolegliwości bólowych oraz poprawy funkcjonalnej u pacjentów z zespołem de Querveina przy zastosowaniu różnych metod fizjoterapeutycznych i ich kombinacji. Niestety, istnieje mała liczba randomizowanych badań klinicznych, stąd też trudno jest wyciągnąć jednoznaczne wnioski dotyczące wskazania najefektywniejszych form leczenia. Wymagane są dalsze badania skupione na poszukiwaniu zintegrowania najskuteczniejszych metod fizjoterapeutycznych leczenia zespołu de Quervaina oraz oceny efektów krótko i długoterminowych.

Słowa kluczowe: zapalenie ścięgna, rozpoznanie, leczenie, de Quervain, fizjoterapia

Zaworski K. Functional diagnostics and physiotherapeutic treatment in de Quervain syndrome. Health Prob Civil. 2020; 14(4): $305-313$. https://doi.org/10.5114/hpc.2020.95502

Address for correspondence / Adres korespondencyjny: Kamil Zaworski, Pope John Paul II State School of Higher Education, Sidorska 95/97, 21-500 Biała Podlaska, Poland, e-mail: kamil_zaworski@wp.pl, phone: +48 83 344 99 00, ORCID: Kamil Zaworski https://orcid.org/0000-0001-5604-1862

Copyright: ( C Pope John Paul II State School of Higher Education in Biała Podlaska, Kamil Zaworski. This is an Open Access journal, all articles are distributed under the terms of the Creative Commons Attribution-NonCommercial-ShareAlike 4.0 International (CC BY-NC-SA 4.0) License (http://creativecommons.org/licenses/ by-nc-sa/4.0/), allowing third parties to copy and redistribute the material in any medium or format and to remix, transform, and build upon the material, provided the original work is properly cited and states its license. 


\section{Introduction}

De Quervain syndrome is an inflammatory condition involving the narrowing or inflammation of the synovial membrane of the common tendon sheath of the abductor pollicis longus (APL) and the extensor pollicis brevis (EPB) in the region of the radial styloid process. Tendon sheaths have the shape of the tube covering muscle tendons. They consist of two layers composed of laminae - external fibrous and internal - synovial. Tendon sheaths reduce friction and facilitate the sliding movements of the tendon on the bone. They also maintain their proper position against the bone [1].

The condition occurs in $0.5 \%$ of working men and $1.3 \%$ of working women. It is more common in women going through menopause, pregnancy or the postpartum period. It does not have to involve the dominant hand [2].

The cause of the condition has not been fully explained [3]. De Quervain syndrome can be caused by microtraumas that occur in the course of repetitive mechanical activities as well as systemic diseases of the connective tissue, such as rheumatoid arthritis [1]. The name of the condition comes from Fritz de Quervain who was the first to describe it in 1895 [4]. The syndrome is often referred to as "mother's thumb" because it occurs more frequently in breastfeeding women. It is associated with strain that is put on tendons when carrying a child and the swelling of soft tissues, fluid retention and flaccid ligaments, which are the consequence of pregnancy hormones [5]. Increasingly younger people are at risk of tenosynovitis due to the development of modern technology and the frequent use of cell phones, tablets and consoles by children and adults [6-8]. Ali and colleagues showed that frequent texting is associated with the occurrence of de Quervain syndrome among students [6].

The first symptom of de Quervain syndrome is peritonitis or tenosynovitis. Followed by fibrosis and thickening, a secondary inflammatory and repair reaction of the retinaculum of the first extensor compartment occurs. The retinaculum can be damaged and regenerated multiple times as the condition progresses, which in turn leads to the formation of a degenerated scar. Pain is caused by an oversized and fibrotic retinaculum, which is too flexed because of the pressure from the tendons, during the extension and flexion of the wrist and thumb [2].

Physiotherapeutic treatment is an important element of conservative treatment of de Quervain syndrome. About $40 \%$ of patients suffering from this condition are referred to a physiotherapist by their GP [9]. Therefore, there is a strong need to look for the most effective physiotherapeutic methods and their combinations to treat this syndrome.

The article aims to present functional diagnostics and physiotherapeutic methods that are used in the treatment of de Quervain syndrome based on the available literature.

\section{Diagnostics}

Diagnostic examination begins with an interview in which attention should be paid to information correlated with repeated overstraining of the upper limb. Patients tend not to remember the immediate moment of damage, and the problem develops gradually. An important piece of information concerns the occurrence of forearm pain at the height of the radial styloid process which increases during the extension of the thumb. Other symptoms include redness and swelling in the region. [1].

The physical examination most often involves two tests: Finkelstein's test and Eichhoff's test. Finkelstein's test has long been recognized as a pathognomonic symptom of de Quervain syndrome. Most clinicians perform this test erroneously using the Eichhoff's test methodology [10].

During Finkelstein's test, the patient's wrist should be on the edge of a table and the hand off the tabletop. The patient is asked to perform an active adduction of the wrist joint towards the elbow and then the examiner grips the patient's thumb and bends it passively towards the hand. Pain that occurs in the region of the first extensor tendon compartment is interpreted as a positive result of the test $[6,7,10]$.

Eichhoff's test begins with the patient actively placing the thumb in the palm and clenching the remaining fingers. The hand is then passively bent by the examiner in the direction of the elbow. The therapist can palpate the areas of the APL and EPB tendons while performing both tests. They should pay attention to any crackling, movement disorder and the shape of the tendons [10].

The disadvantage of both tests is the mechanism of stretching all soft tissues in the region of the first extensor compartment. This can cause pain symptoms in adjacent structures, such as ligaments [11]. In addition, Eichhoff's test can cause pain coming from the structures of joints. Both tests can also trigger pain symptoms in healthy patients [10]. Wu et al. compared the sensitivity and specificity of both tests in a group of 36 patients. The 
presented results indicated that Finkelstein's test shows greater sensitivity and specificity and is recommended by the authors to diagnose de Quervain syndrome [10].

The average level of reliability of the tests suggests that imaging tests may be helpful. Ultrasonography (USG) and magnetic resonance imaging (MRI) are most commonly used to diagnose peritonitis. When performing an ultrasound examination, we initially observe an effusion in the tendon sheath and then synovial hypertrophy, fibrous changes and calcifications within the tendon sheath [1].

Differential diagnosis of patients with wrist pain in the area of the radial styloid process should also include C6 radiculopathy, wrist instability, fractures of the styloid process and degenerative changes in the metacarpophalangeal joint of the thumb and wrist joints. Radiological tests may be helpful in these cases [12].

\section{Physiotherapeutic treatment}

\section{Acute phase}

Physiotherapeutic treatment of de Quervain syndrome is divided into three main sections - kinesitherapy, physical therapy and therapeutic massage. This division was employed in the following review and it was also expanded to include physioprophylaxis and education, kinesiotaping and acupuncture. All the publications have been grouped and presented in Table 1.

Table 1. Author's list and classification of publications discussed in the following review

\begin{tabular}{|c|c|c|c|c|}
\hline $\begin{array}{c}\text { Authors and } \\
\text { year }\end{array}$ & $\begin{array}{c}\text { Research } \\
\text { credibility } \\
\text { level }\end{array}$ & $\begin{array}{l}\text { The } \\
\text { number of } \\
\text { subjects }\end{array}$ & $\begin{array}{l}\text { Used treatment } \\
\text { methods }\end{array}$ & Conclusions \\
\hline $\begin{array}{l}\text { Sharma R, et al. } \\
\quad 2002[22]\end{array}$ & $1 \mathrm{~A}$ & 30 & Low-level laser & $\begin{array}{l}\text { Laser therapy does have a therapeutic effect on de } \\
\text { Quervain's tenosynovitis as has been shown by the } \\
\text { reduction in antero-posterior and medio-lateral } \\
\text { diameters of the tendon sheaths and improved clinical } \\
\text { parameters in this study. }\end{array}$ \\
\hline $\begin{array}{l}\text { Hasan T, et al. } \\
2014 \\
{[24]}\end{array}$ & $1 \mathrm{~B}$ & 50 & $\begin{array}{l}\text { Phonophoresis, } \\
\text { stabilisation } \\
\text { splint, stretching } \\
\text { and strengthening } \\
\quad \text { exercises }\end{array}$ & $\begin{array}{l}\text { Ketoprofen phonophoresis as an adjunct to a supervised } \\
\text { exercise regime and splint immobilisation is a promising } \\
\text { therapy for de Quervain's tenosynovitis during } \\
\text { pregnancy. It is safe and provides symptomatic and } \\
\text { functional relief of the condition, which makes it an ideal } \\
\text { therapy for pregnant females. }\end{array}$ \\
\hline $\begin{array}{l}\text { Hadianfard M, } \\
\text { et al. } \\
2014 \\
\text { [35] }\end{array}$ & $1 \mathrm{~B}$ & 30 & $\begin{array}{l}\text { Corticosteroid } \\
\text { injections, } \\
\text { acupuncture }\end{array}$ & $\begin{array}{l}\text { We demonstrated short-term improvement of pain } \\
\text { and function in both groups. Although the success rate } \\
\text { was somewhat higher with corticosteroid injection, } \\
\text { acupuncture can be considered as an alternative option } \\
\text { for the treatment of de Quervain's tenosynovitis. }\end{array}$ \\
\hline $\begin{array}{l}\text { Jongprasitkul H } \\
2011 \\
{[34]}\end{array}$ & $1 \mathrm{~B}$ & 40 & $\begin{array}{l}\text { Elastic bandage, } \\
\text { stabilising rail }\end{array}$ & $\begin{array}{l}\text { In conclusion, there was no significant difference in pain } \\
\text { reduction and strength improvement between using } \\
\text { the bandage and the splint as far as acute de Quervain's } \\
\text { tenosynovitis is concerned. }\end{array}$ \\
\hline $\begin{array}{l}\text { Kacmaz IE, et al. } \\
2019 \\
{[33]}\end{array}$ & $2 \mathrm{~A}$ & 20 & Kinesiotaping & $\begin{array}{l}\text { In conclusion, we believe that kinesiology taping is } \\
\text { a cheap, effective, and easy to implement treatment } \\
\text { method with no complications, and thus a good } \\
\text { alternative in the conservative treatment of de } \\
\text { Quervain's tenosynovitis. }\end{array}$ \\
\hline $\begin{array}{l}\text { Babaji GA, et al. } \\
2017 \\
{[17]}\end{array}$ & $2 \mathrm{~A}$ & 52 & $\begin{array}{l}\text { MDT exercises, } \\
\text { PRP, ultrasound, } \\
\text { cryotherapy }\end{array}$ & $\begin{array}{l}\text { Combination therapy (MDT }+ \text { PRP }+ \text { Conventional } \\
\text { therapy) has maximal effect in subjects with de } \\
\text { Quervain's tenosynovitis. MDT along with conventional } \\
\text { treatment \& PRP along with conventional treatment } \\
\text { have an average effect in the treatment of de Quervain's } \\
\text { tenosynovitis. And conventional treatment alone has } \\
\text { minimal effect on the same. }\end{array}$ \\
\hline $\begin{array}{l}\text { Homayouni K, } \\
\text { et al. } \\
2013 \\
{[25]}\end{array}$ & $2 \mathrm{~A}$ & 60 & $\begin{array}{l}\text { Kinesiotaping, } \\
\text { paraffin baths, } \\
\text { underwater } \\
\text { ultrasound, TENS, } \\
\text { deep transverse } \\
\text { friction massage }\end{array}$ & $\begin{array}{l}\text { The results revealed that patients with de Quervain's } \\
\text { disease respond more favourably to KT rather than PT. }\end{array}$ \\
\hline
\end{tabular}




\begin{tabular}{|c|c|c|c|c|}
\hline $\begin{array}{c}\text { Katana B, et al. } \\
2012 \\
{[13]}\end{array}$ & $2 \mathrm{~B}$ & 50 & $\begin{array}{l}\text { Immobilisation, } \\
\text { cryotherapy, } \\
\text { TENS, ultrasound, } \\
\text { diadynamic } \\
\text { therapy, magnetic } \\
\text { field, therapeutic } \\
\text { massage, active } \\
\text { exercises } \\
\end{array}$ & $\begin{array}{l}\text { Physical therapy and kinesiotherapeutic procedures } \\
\text { have greatly contributed to the elimination of symptoms } \\
\text { and consequences of de Quervain disease. }\end{array}$ \\
\hline $\begin{array}{l}\text { Rabin A, et al. } \\
2015 \\
{[15]}\end{array}$ & 3 & 4 & $\begin{array}{c}\text { Mobilization } \\
\text { with movement } \\
\text { (MWM), eccentric } \\
\text { exercises, } \\
\text { resistance } \\
\text { training exercises }\end{array}$ & $\begin{array}{l}\text { A multi-modal physiotherapy treatment resulted in } \\
\text { a successful outcome in three out of four people with } \\
\text { DQD. This treatment protocol may represent a viable line } \\
\text { of conservative care with fewer risks than corticosteroid } \\
\text { injections. A randomized controlled trial to assess the } \\
\text { efficacy of this treatment seems warranted. }\end{array}$ \\
\hline $\begin{array}{l}\text { Machnia M, et al. } \\
2015 \\
{[26]}\end{array}$ & 3 & 1 & $\begin{array}{l}\text { Low-frequency } \\
\text { electromagnetic } \\
\quad \text { field }\end{array}$ & $\begin{array}{l}\text { 1. Low-frequency electromagnetic field therapy with } \\
\text { complex parameters used alternately and consecutively } \\
\text { during one treatment showed good efficacy in the } \\
\text { treatment of de Quervain syndrome. } \\
\text { 2. The use of biofeedback is an effective method to } \\
\text { determine individually tailored parameters of PEMF } \\
\text { therapy. }\end{array}$ \\
\hline $\begin{array}{l}\text { Papa JA. } \\
2012 \\
{[14]}\end{array}$ & 3 & 1 & $\begin{array}{l}\text { Eccentric and } \\
\text { endurance } \\
\text { exercises }\end{array}$ & $\begin{array}{l}\text { DQST shares histopathological and clinical } \\
\text { characteristics similar to other tendinopathies. This } \\
\text { case demonstrates the management of DQST using } \\
\text { conservative interventions that can be employed by } \\
\text { chiropractic practitioners. Although favourable results } \\
\text { were obtained, it is important to note that the nature of } \\
\text { this investigation was that of a case study, and therefore } \\
\text { the utilized treatment protocol may not be appropriate } \\
\text { for all individuals presenting with DQST. }\end{array}$ \\
\hline $\begin{array}{l}\text { Howell ER. } \\
\quad 2012 \\
{[12]}\end{array}$ & 3 & 1 & $\begin{array}{l}\text { Kinesiotaping, } \\
\text { manual therapy } \\
\text { (soft tissue } \\
\text { therapy }+ \\
\text { mobilization), } \\
\text { acupuncture, } \\
\text { cryotherapy, } \\
\text { eccentric training }\end{array}$ & $\begin{array}{l}\text { The results of this case may suggest that conservative } \\
\text { treatment may be useful in treating de Quervain's } \\
\text { disease before more invasive procedures are pursued. }\end{array}$ \\
\hline $\begin{array}{l}\text { Kaneko S, et al. } \\
2009 \\
{[16]}\end{array}$ & 3 & 1 & MDT exercises & $\begin{array}{l}\text { The pain was rapidly and successfully treated with } \\
\text { the application of ulnar deviation with radio-carpal } \\
\text { distraction. This case study introduces a novel method } \\
\text { of examining and classifying wrist and thumb problems } \\
\text { that might be able to produce rapid therapeutic effects. }\end{array}$ \\
\hline $\begin{array}{l}\text { Backstrom KM. } \\
2002 \\
{[20]}\end{array}$ & 3 & 1 & $\begin{array}{l}\text { Mobilization } \\
\text { with movement } \\
\text { (MWM), } \\
\text { iontophoresis, } \\
\text { cryotherapy, } \\
\text { deep friction } \\
\text { transverse } \\
\text { massage }\end{array}$ & $\begin{array}{l}\text { The combination of conventional physical agents, } \\
\text { exercise and manual therapy as well as the less } \\
\text { conventional MWM techniques proved successful with } \\
\text { this patient. }\end{array}$ \\
\hline
\end{tabular}

\section{Kinesitherapy}

\section{Eccentric exercises}

In the course of treating de Quervain syndrome, eccentric exercises and free active exercises aimed at improving the sliding between the APL and EPB tendons are used first [13-15]. They are done in a pain-free range. As the patient's pain tolerance increases the range of motion is also increased. In the case study carried out by Papa, the author recommended eccentric exercises of thumb extension and abduction, wrist flexion and extension as well as forearm pronation [14]. The effectiveness of eccentric training in combination with other forms of therapy was also confirmed by the case study described by Howell [12]. 
Rabin and colleagues also presented a combination of eccentric and strength exercises combined with mobilization with movement (MWM). They obtained satisfactory treatment results in 3 out of 4 patients [15].

\section{The McKenzie method (MDT)}

In the case study described by Kaneko and coauthors, MDT (mechanical diagnosis and therapy) exercises developed by McKenzie were used. The female patient performed 10-20 repetitions of the exercise every three hours in a pain-free range. Two weeks after the start of therapy, the subject did not report any pain symptoms [16].

Babaji and Shinde compared the effectiveness of the exercises in the McKenzie concept (MDT) with the administration of platelet rich plasma (PRP). The authors divided 60 patients into four groups, each of which participated in ultrasound and cryotherapy treatments. Group B additionally did McKenzie exercises, group C received PRP, and group D did both the exercises and were injected with PRP. After three weeks of therapy, it was noted that the combination of physical therapy, exercise and PRP (group D) was significantly more effective in reducing pain and improving the range of thumb mobility compared to the methods used in the other groups [17].

\section{Virtual reality rehabilitation games}

Electronic devices such as tablets and smartphones as well as specialized programmes in the form of rehabilitation computer games can be used to treat the syndrome nowadays. In this context, the importance of increased motivation to achieve therapeutic goals is emphasized. The task of rehabilitation using electronic devices is to restore lost motor functions of the hand. This includes doing specific exercises requiring, among others, repeated movements with the possibility of feedback as a form of additional stimulation and motivation. The authors of some studies emphasized that it is necessary to personalize exercise programmes and adapt them to the stage and advancement of de Quervain syndrome [18,19].

\section{Manual therapy}

In the case study described by Backstrom, a patient with de Quervain syndrome underwent mobilization with movement (MWM) in combination with ionophoresis, cryotherapy and deep transverse friction massage (DTFM). The specific MWM techniques that were used involved active thumb and wrist movements as well as passive radial slide of wrist bones in the proximal row [20]. Mobilization with movement was also used in a number of cases described by Rabin et al. [15].

\section{Physiotherapy}

\section{Laser therapy}

Laser therapy is one of the most commonly used physiotherapeutic treatments in physiotherapy. The laser reduces the conduction of pain stimuli in afferent fibres as well as vasodilatory and angiogenic effects. This results in the improvement of peripheral circulation and microcirculation. Collagen synthesis and enzyme regulation processes are also stimulated [21].

In their study, Sharma and colleagues evaluated the effectiveness of treatment with a low-level energy laser. The subjects were randomly assigned to the placebo group $(n=15)$ and the study group (n=15) in which a continuous beam of $2-4 \mathrm{~J} / \mathrm{cm} 2$ was used. After the end of the treatment, the authors noted significant alleviation of pain symptoms and increased grip strength among the patients in the study group, while there was no improvement in the placebo group [22].

\section{Ultrasound}

Research conducted by Babaji et al. as well as the study by Katana and coauthors showed that the use of ultrasound in patients with de Quervain syndrome helped to alleviate pain and reduce tonicity [13,17]. This method uses ultrasonic waves that are applied in a given area to improve circulation, reduce swelling and promote tissue and tendon healing [17]. The treatment parameters are selected individually, but the most publications recommends the frequency of $3 \mathrm{MHz}$ and a dose from 0 to $2.0 \mathrm{~W} / \mathrm{cm}[17,23]$. 
Hasan and Fauzi evaluated the effectiveness of phonophoresis with $2.5 \%$ ketonal in the treatment of de Quervain syndrome in women in the third trimester of pregnancy in combination with splints and exercise. The authors used ultrasound, splints and training in the control group. They observed obvious and statistically significant differences in favour of the phonophoresis group [24].

\section{Electrotherapy}

As evidenced by the available literature, electrotherapy in the form of diadynamic therapy, iontophoresis and TENS was used only as one of the forms of therapy correlated with other procedures $[13,20,25]$. The positive effect of the treatment was statistically significant in all the studies.

\section{Low-frequency magnetic field}

Magnetic fields are widely used in the physiotherapeutic treatment of muscular and joint problems. The impact of a magnetic field is based on its analgesic and anti-inflammatory effect. It also increases oxygen utilization processes and blood flow through tissues [21]. The case study presented by Machnia and colleagues talked about a patient with de Quervain syndrome who was treated with a low-frequency electromagnetic field with complex parameters. Four weeks after the beginning of the magnetotherapy ( 7 days after the last treatment session), the subject did not report any pain. However, the authors drew attention to the strong need to individualize the parameters of the treatment [26]. Statistically significant improvement was also noted by Katana et al. who used a magnetic field as an element of a combination therapy in patients with chronic conditions [13].

\section{Cryotherapy}

Local effects of cold in the first phase include reduction of conductivity in sensory nerves and angioneurotic changes [21]. These effects may support the treatment process in de Quervain syndrome by alleviating symptoms accompanying inflammation. The available literature shows that cryotherapy was used as a combination therapy with other physical therapy treatments, manual therapy and eccentric training $[12,13,17]$. Some authors reported a statistically significant reduction in the level of pain and an improvement in the functional level among the patients $[13,17]$.

\section{Therapeutic massage}

Some authors recommend a soft tissue massage in the first tendon compartment [12]. It aims to relax the muscles and improve fluid drainage and reduce swelling. Massage as one of the elements of combination therapy was used in the studies by Katana and colleagues. The authors recommended its use only in the case of chronic conditions [13].

In the studies by Homayouni et al., and Backstrom, deep transverse friction massage (DTFM) was used in combination with physiotherapeutic treatments [25]. DTFM is one of the manual therapeutic techniques described by James Cyriax. The task is to preserve tissue mobility and to prevent the formation of adhesions and scars in the healing structure [27]. A satisfactory therapeutic effect was observed in both cited publications [20, 25].

\section{Physioprophylaxis and education}

Huisstede and colleagues indicated the need, especially in the acute state, to avoid movements that cause pain. These movements included flexion of the thumb and adduction of the wrist joint. It was also recommended to avoid repetitive movements in these joints [28]. It is necessary to educate the patient on how to perform daily activities and to provide them with instructions on how to modify activities that are associated with the occurrence of the syndrome, e.g. mother holding a child so that it is safer. It is worth considering ergonomic keyboards and device modifications that allow for neutral positioning of the wrist joint in the case of office workers [28-30].

\section{Kinesiotaping}

Kinesiology tape is considered to be a conservative method for treating de Quervain syndrome. It is used to reduce pain, swelling and inflammation [31]. Orthoses used in orthopaedic treatment immobilise inflamed 
tissues, providing protection for damaged structures. However, too long immobilization can lead to secondary, negative physiological and biomechanical changes in the tissue. Kinesiology tape makes it possible for the healing tissues to move and, depending on the taping technique, it can support movement and increase lymphatic drainage of tissues [32]. However, there are no clear guidelines in the literature on how to use the tape and how long it should be used. Kacmaz et al. used kinesiotaping once a week for one month in 20 patients who were diagnosed with de Quervain syndrome. After the treatment, the authors reported a statistically significant reduction in the level of pain and disability [33]. Homayouni and colleagues conducted studies comparing the effectiveness of kinesiotaping $(n=30)$ and physiotherapeutic treatments $(n=30)$. The authors noted statistically greater reduction in pain and swelling in the group of patients who used kinesiology tape [25]. Case study described by Howell proposed the use of kinesiotaping in combination with manual therapy and eccentric training [12].

Taking into account the ways in which kinesiotaping works, this method should be considered in terms of protecting damaged structures and replacing elastic bandage or orthoses. Jongprasitku and colleagues compared the effectiveness of an elastic bandage and an orthosis in the treatment of the syndrome. Both groups consisted of 20 participants, who wore a bandage or an orthosis for a minimum of six hours per day for a period of 2 weeks. The authors did not report statistically significant differences between the groups during this period [34].

\section{Acupuncture}

Acupuncture is also mentioned among the methods for treating de Quervain syndrome. Traditional Chinese medicine was recognized by the World Health Organization as a conventional form of treatment in 2019. Hadianfard et al. compared the effectiveness of de Quervain syndrome treatment with corticosteroid injections $(\mathrm{n}=15)$ and acupuncture $(\mathrm{n}=15)$. Both methods significantly reduced pain and improved functionality. Injections showed greater effectiveness, and the authors recommended acupuncture for consideration as a supportive therapy [35]. This suggestion is confirmed by the case study described by Howell, in which acupuncture brought good treatment results in connection with manual therapy techniques and eccentric exercises [12].

\section{Remission phase}

Physiotherapeutic procedures in the form of warm compresses, partial baths of the upper limb at $35-37^{\circ} \mathrm{C}$, hydro-massage baths and showers with rain heads can be used during the remission phase of de Quervain syndrome [36-38]. Balneotherapy with mud and therapeutic mud is also used during the treatment process due to the anti-inflammatory, astringent and hyperaemic effects [36-38]. There are no publications describing the treatment of de Quervain syndrome in the remission phase.

\section{Conclusions}

De Quervain syndrome is a condition that reduces the life quality of patients due to the occurrence of significant pain and limitations in their everyday functioning. Physiotherapy is one of the options for conservative treatment characterized by low invasiveness and low costs. It should be noted that physiotherapeutic methods used in isolated form are just as effective as corticosteroid injections. This conclusion was indicated in the metaanalysis by Cavaleri and colleagues [39].

An important factor that should be considered is the combination of different forms of physiotherapy. Unfortunately, there are a small number of randomized clinical trials. Hence, it is difficult to draw definite conclusions. Further research is required in order to achieve the integration of the mosteffective physiotherapeutic methods in the treatment of de Quervain syndrome and the assessment of its short and long-term effects.

\section{References:}

1. Jeka S, Dura M, Waszczak-Jeka M. Ultrasonography for the most common pain syndromes of the upper extremity in the outpatients clinical practice. Forum Reumatol. 2016; 2(3): 111-117.

2. Dębek A, Czyrny Z, Nowicki P. Sonography of pathological changes in the hand. Journal of Ultrasonography. 2014; 14: 74-88. https://doi.org/10.15557/JoU.2014.0007

3. Patel KR, Tadisina KK, Gonzalez MH. De Quervain's disease. Eplasty. 2013; 13: ic52

4. De Quervain F. [On a form of chronic tendovaginitis]. Korrespondenzblatt für Schweiz Arzte. 1895; 25: 389394 (in German). 
5. Borg-Stein J, Dugan SA. Musculoskeletal disorders of pregnancy, delivery and postpartum. Phys Med Rehabil Clin N Am. 2007; 18: 459-476. https://doi.org/10.1016/j.pmr.2007.05.005

6. Ali M, Asim M, Danish SH, Ahmad F, Iqbal A, Hasan SD. Frequency of de Quervain's tenosynovitis and its association with SMS texting. Muscles, Ligaments and Tendons Journal. 2014; 4(1): 74-77.

7. Ashurst JV, Turco DA, Lieb BE. Tenosynovitis caused by texting: an emerging disease. JAOA: Journal of the American Osteopathic Association. 2010; 110(5): 294-296.

8. Traverso AM, Douek P, Schivo D, Bruyère C, Müller CT, Krähenbühl SM, et al. De Quervain tenosynovitis in a 12-year-old child: a generation's disease?. J Orthop Surg Tech. 2017; 1(2): 29-32.

9. Feleus A, Bierma-Zeinstra SM, Miedema HS, Verhaar JA, Koes BW. Management in non-traumatic arm, neck and shoulder complaints: differences between diagnostic groups. Eur Spine J. 2008; 17: 1218-1229. https://doi.org/10.1007/s00586-008-0710-1

10. Wu F, Rajpura A, Sandher D. Finkelstein's test is superior to Eichhoff's test in the investigation of de Quervain's disease. J Hand Microsurg. 2018; 10: 116-118. https://doi.org/10.1055/s-0038-1626690

11. Elliott BG. Finkelstein's test: a descriptive error that can produce a false positive. J Hand Surg [Br]. 1992; 17(4): 481-482. https://doi.org/10.1016/S0266-7681(05)80280-3

12. Howell ER. Conservative care of de Quervain's tenosynovitis/tendinopathy in a warehouse worker and recreational cyclist: a case report. J Can Chiropr Assoc. 2012; 56(2): 121-127.

13. Katana B, Jaganjac A, Bojičić S, Hadžiomerović AM, Pecar M, Kaljić E, etal. Effectiveness of physical treatment at de Quervain's disease. Journal of Health Sciences. 2012; 2(1): 80-84. https://doi.org/10.17532/jhsci.2012.88

14. Papa JA. Conservative management of de Quervain's stenosing tenosynovitis: a case report. J Can Chiropr Assoc. 2012; 56(2): 112-120.

15. Rabin A, Israeli T, Kozol Z. Physiotherapy management of people diagnosed with de Quervain's disease: a case series. Physiotherapy Canada. 2015; 67(3): 263-267. https://doi.org/10.3138/ptc.2014-47

16. Kaneko S, Takasaki H, May S. Application of mechanical diagnosis and therapy to a patient diagnosed with de Quervain's disease: a case study. Journal of Hand Therapy. 2009; 22(3): 278-283. https://doi.org/10.1016/j.jht.2009.03.002

17. Babaji GA, Shinde SB. Effect of the Mckenzie's method of mechanical diagnosis and therapy and pain releasing phenomenon in subjects with de Quervain's tenosynovitis. Indian Journal of Physiotherapy and Occupational Therapy. 2017; 11(3): 162-168. https://doi.org/10.5958/0973-5674.2017.00096.X

18. Algar L, Valdes K. Using smartphone applications as hand therapy interventions. J Hand Ther. 2014; 27(3): 254-257. https://doi.org/10.1016/j.jht.2013.12.009

19. Szczechowicz J, Pieniążek M. Rehabilitation of patients after traumatic injuries to the hand and during the course of upper limb enthesopathic syndromes using personal electronic devices - a preliminary report. Med. Rehabil. 2018; 22(1): 49-53. https://doi.org/10.5604/01.3001.0012.0774

20. Backstrom KM. Mobilization with movement as an adjunct intervention in a patient with complicated de Quervain's tenosynovitis: a case report. J Orthop Sports Phys Ther. 2002; 32(3): 86-94. https://doi.org/10.2519/jospt.2002.32.3.86

21. Ward A, Robertson V, Low J, Reed A. [Physical therapy. Clinical and biophysical aspects. $1^{\text {st }}$ Polish edition]. Wrocław: Edra Urban \& Partner; 2009 (in Polish).

22. Sharma R, Thukral A, Kumar S, Bhargava SK. Effect of low level lasers in de Quervain's tenosynovitis: prospective study with ultrasonographic assessment. Physiotherapy. 2002; 88(12): 730-734. https://doi.org/10.1016/S0031-9406(05)60716-X

23. Hartzell TL, Rubenstein R, Herman M. Therapeutic modalities - an updated review for the hand surgeon. J Hand Surg. 2013; 37A: 597-621. https://doi.org/10.1016/j.jhsa.2011.12.042

24. Hasan T, Fauzi M. De Quervain's tenosynovitis and phonophoresis: a randomised controlled trial in pregnant females. Journal of Orthopaedics, Trauma and Rehabilitation. 2015; 19(1): 2-6. https://doi.org/10.1016/j.jotr.2014.04.001

25. Homayouni K, Zeynali L, Mianehsaz E. Comparison between kinesiotaping and physiotherapy in the treatment of de Quervain's disease. Journal of Musculoskeletal Research. 2013; 16(4): 1350019. https://doi.org/10.1142/S021895771350019X

26. Machnia M, Cichoń N, Miller E. Individualised low frequency magnetic field therapy, using the example of the de Quervain syndrome. Fizjoterapia Polska. 2015; 4(15): 116-122.

27. Buckwalter JA. The effects of early motion on healing of musculoskeletal tissues. Hand Clin. 1996; 12(1): 13-24.

28. Huisstede BMA, Coert JH, Friden J, Hoogvliet P. Consensus on a multidisciplinary treatment guideline for de Quervain disease: results from the European HANDGUIDE study. Phys Ther. 2014; 94: $1095-1110$. https://doi.org/10.2522/ptj.20130069 
29. Goel R, Abzug JM. De Quervain's tenosynovitis: a review of the rehabilitative options. Hand. 2015; $10: 1-5$. https://doi.org/10.1007/s11552-014-9649-3

30. Rees JD, Maffulli N, Cook J. Management of tendinopathy. Am J Sports Med. 2009; 37(9): 1855-1867. https://doi.org/10.1177/0363546508324283

31. Homayouni K, Foruzi S, Kalhori F. Effects of kinesiotaping versus non-steroidal anti-inflammatory drugs and physical therapy for treatment of pes anserinus tendino-bursitis: a randomized comparative clinical trial. Phys Sportsmed. 2016; 44(3): 252-256. https://doi.org/10.1080/00913847.2016.1199251

32. Williams S, Whatman C, Hume PA, Sheerin K. Kinesiotaping in treatment and prevention of sports injuries: a meta-analysis of the evidence for its effectiveness. Sports Med. 2012; 42: 153-164. https://doi.org/10.2165/11594960-000000000-00000

33. Kaçmaz IE, Koca A, Basa CD, Zhamilov V, Reisoğlu A. Efficacy of kinesiologic taping in de Quervain's tenosynovitis: case series and review of literature. Bakırköy Tıp Dergisi. 2019; 15: 227-231. https://doi.org/10.4274/BTDMJB.galenos.2019.20180815084330

34. Jongprasitkul H, Suputtitada A, Kitisomprayoonkul W, Pintawiruj K. Elastic bandage vs. neoprene thumb stabilizer splint in acute De Quervain's tenosynovitis. Asian Biomedicine. 2011; 5(2): 263-267. https://doi.org/10.5372/1905-7415.0502.035

35. Hadianfard M, Ashraf A, Fakheri M, Nasiri A. Efficacy of acupuncture versus local methylprednisolone acetate injection in De Quervain's tenosynovitis: a randomized controlled trial. JAMS journal of acupuncture and meridian studies. 2014; 7(3): 115-121. https://doi.org/10.1016/j.jams.2013.10.003

36. Ponikowska I, Kochański JW. [The great book of balneology, physical and spa medicine. Volume 2, Clinical part]. Konstancin-Jeziorna: Alun; 2018 (in Polish).

37. Kasprzak W, Mańkowska A. [Physical therapy, spa medicine and spa]. Warszawa: PZWL Wydawnictwo Lekarskie; 2019 (in Polish).

38. Mika T, Kasprzak W. [Physical therapy]. Warszawa: PZWL Wydawnictwo Lekarskie; 2019 (in Polish).

39. Cavaleri R, Schabrun SM, Te M, Chipchase LS. Hand therapy versus corticosteroid injections in the treatment of de Quervain's disease: a systematic review and meta-analysis. Journal of Hand Therapy. 2016; 29: 3-11. https://doi.org/10.1016/j.jht.2015.10.004 